\title{
Synthesis and characterization of the complexes of some transition metals with 2-acetyl pyridine (N-benzoyl) glycyl hydrazone
}

\author{
R K LONIBALA ${ }^{\mathrm{a} *}$ and T R RAO \\ ${ }^{a}$ Chemistry Department, Manipur University, Canchipur 795003 , India \\ ${ }^{b}$ Department of Chemistry, Banaras Hindu University, Varanasi 221005 , \\ India
}

MS received 26 October 1998; revised 31 March 1999

\begin{abstract}
Complexes of $\mathrm{Mn}$ (II), $\mathrm{Co}$ (II), $\mathrm{Ni}(\mathrm{II}), \mathrm{Cu}(\mathrm{II}), \mathrm{Zn}$ (II), $\mathrm{Cd}(\mathrm{II})$ and $\mathrm{Hg}$ (II) with 2 -acetyl pyridine (N-benzoyl) glycyl hydrazone(2-ApBzGH) have been synthesized and characterized by elemental analyses, molar conductances, magnetic susceptibility, IR, electronic, ESR, ${ }^{1} \mathrm{H},{ }^{13} \mathrm{C}$ and ${ }^{113} \mathrm{Cd}$ NMR spectral and $\mathrm{X}$-ray diffraction studies. IR and NMR data suggest the tridentate nature of the ligand coordinating as a neutral species in the addition complexes and as a uninegative species in the deprotonated complexes. The presence of more than one isomer of the ligand has been established by ${ }^{1} \mathrm{H}$ NMR spectra of the ligand and complexes recorded over the 298-396 $\mathrm{K}$ range. The $\mathrm{X}$-ray powder diffraction patterns of $[\mathrm{Cd}(2-\mathrm{ApBzGH}) \mathrm{Cl}] \mathrm{Cl}$ and $[\mathrm{Cu}(2-$ $\mathrm{ApBzGH}) \mathrm{Cl}\left(\mathrm{H}_{2} \mathrm{O}\right)_{2} \mathrm{lCl}$ are indexed for orthorhombic and tetragonal crystal systems respectively.
\end{abstract}

Keywords. Transition complexes; 2-acetylpyridine ( $N$-benzoyl)glycyl hydrazone; isomer; tridentate ligand.

\section{Introduction}

As a part of our systematic investigation on the $3 d$ and $4 \mathrm{f}$ metal complexes of various hydrazides $^{1,2}$ and their schiff bases ${ }^{3-7}$, we report here the results of our studies on the syntheses and spectral features of complexes of 2-acetylpyridine ( $\mathrm{N}$-benzoyl)glycyl hydrazone (2-ApBzGH; figure 1) with $\mathrm{Mn}(\mathrm{II}), \mathrm{Co}(\mathrm{II}), \mathrm{Ni}(\mathrm{II}), \mathrm{Cu}(\mathrm{II}), \mathrm{Zn}(\mathrm{II}), \mathrm{Cd}(\mathrm{II})$ and $\mathrm{Hg}$ (II).

\section{Experimental}

\subsection{Materials and methods}

All the chemicals used in the present study were of $\mathrm{BDH}$ grade or of an equivalent quality. 2-ApBzGH was prepared as reported ${ }^{8}$ and was confirmed by mass, IR, ${ }^{1} \mathrm{H}$ and ${ }^{13} \mathrm{C}$ NMR spectra, m.p. $192-193^{\circ} \mathrm{C}$ (Lit. $191-193^{\circ} \mathrm{C}$ ). Found: C 64.74; H 5.40; N 18.88; $\mathrm{N}_{2} \mathrm{H}_{4}, 10 \cdot 86 \%$. Calcd: $\mathrm{C}_{10} \mathrm{H}_{16} \mathrm{~N}_{4} \mathrm{O}_{2}: \mathrm{C} 64.79 ; \mathrm{H} 5.40 ; \mathrm{N} 18.90 ; \mathrm{N}_{2} \mathrm{H}_{4}, 10.80 \%$.

*For correspondence 


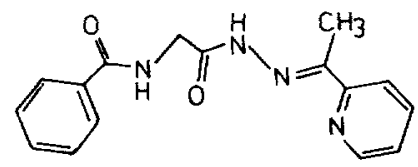

Figure 1. Structure of 2-ApBzGH.

\subsection{Preparation and analysis of the complexes}

2.2a Adduct complexes: Chloromonokis[2-acetyl pyridine ( $N$-benzoyl) glycyl hydrazone] metal(II) chloride, hydrate $[\mathrm{M}(2-\mathrm{ApBzGH}) \mathrm{Cl}] \mathrm{Cl} \cdot \mathrm{nH}_{2} \mathrm{O}[\mathrm{M}=\mathrm{Mn}, \mathrm{Zn}, \mathrm{Cd}, \mathrm{Hg}, n=0$; $\mathrm{M}=\mathrm{Co}, n=2$ ], chloromonokis [2-acetyl pyridine ( $N$-benzoyl)glycyl hydrazone] diaqua metal(II) chloride, $\left[\mathrm{M}(2-\mathrm{ApBzGH}) \mathrm{Cl}\left(\mathrm{H}_{2} \mathrm{O}\right)_{2}\right] \mathrm{Cl}[\mathrm{M}=\mathrm{Cu}, \mathrm{Ni}, n=2]$ were prepared by mixing together the ethanolic solutions of the ligand $\left(\approx 1.0 \mathrm{mmol}\right.$ in $\left.10 \mathrm{~cm}^{-1}\right)$ and the appropriate metal chloride $\left(\approx 1.0 \mathrm{mmol}\right.$ in $\left.10 \mathrm{~cm}^{-1}\right)$ at room temperature. The complexes were either precipitated or precipitation was induced by the addition of $\approx 20 \mathrm{~cm}^{3}$ ether to the reaction mixture.

2.2b Neutral complexes: Bis[2-acetyl pyridine ( $N$-benzoyl)glycyl hydrazonato] metal(II), hydrate $\left[\mathrm{M}(2-\mathrm{ApBzGH}-\mathrm{H})_{2}\right][\mathrm{M}=\mathrm{Co}, \mathrm{Cd}]$, hydroxomonokis [2-acetyl pyridine $(\mathrm{N}$ benzoyl)glycyl hydrazonato] metal(II) $[\mathrm{M}(2-\mathrm{ApBzGH}-\mathrm{H})(\mathrm{OH})][\mathrm{M}=\mathrm{Mn}, \mathrm{Zn}, \mathrm{Hg}]$, hydroxomonokis [2-acetyl pyridine( $N$-benzoyl)glycyl hydrazonato] diaqua metal(II) $\left[\mathrm{M}(2-\mathrm{ApBzGH}-\mathrm{H})(\mathrm{OH})\left(\mathrm{H}_{2} \mathrm{O}\right)_{2}\right] \quad[\mathrm{M}=\mathrm{Cu}, \mathrm{Ni}]$ were synthesized by mixing an aqueous/ethanolic solution of appropriate metal chloride $\left(\approx 1.0 \mathrm{mmol}\right.$ in $\left.20 \mathrm{~cm}^{3}\right)$ and aqueous solution of the potassium salt of the ligand and adjusting the $\mathrm{pH}$ of the solution to $\sim 7$. The resulting complexes were digested on a water bath for $0.5 \mathrm{~h}$. All the complexes prepared as above were filtered and repeatedly washed with suitable solvents and dried either in a desiccator/air. The complexes were analyzed for metal contents employing standard literature procedures ${ }^{9}$ after destroying the organic matter with aqua regia followed by sulphuric acid. Hydrazine was estimated by titrating against $\mathrm{KIO}_{3}$ after subjecting the complexes to acid hydrolysis for $\sim 4 \mathrm{~h}$. Carbon, hydrogen and nitrogen were microanalyzed.

\subsection{Physical measurements}

Molar conductance was measured on a WTW conductivity meter in $10^{-3} \mathrm{M}$ DMSO solution. The magnetic susceptibility measurements were carried out at room temperature on a Cahn-Faraday electrobalance. The electronic spectra were recorded on a Cary-14 spectrophotometer and IR spectra on a Perkin-Elmer 783 spectrophotometer in Nujol. ESR spectra were obtained at $77 \mathrm{~K}$ on a Varian E-line $\mathrm{X}$ band ESR spectrometer using TCNE as a g marker. The ${ }^{1} \mathrm{H},{ }^{13} \mathrm{C}$ and ${ }^{113} \mathrm{Cd}$ NMR spectra were recorded on a Jeol FX$90 \mathrm{Q}$ multinuclear NMR spectrometer. The X-ray powder diffraction patterns were taken by Phillips X-ray diffractometer PW 1710 using $\mathrm{CuK} \alpha$ radiation.

\section{Results and discussion}

The analytical results presented in table 1 show that 2 -ApBzGH reacts with metal(II) chloride yielding complexes of both $1: 1$ and 1:2 metal-ligand stoichiometries. It also 
Table 1. Analytical data and $\mu_{\text {eff }}$ values of the complexes of $2-\mathrm{ApBzGH}$.

\begin{tabular}{|c|c|c|c|c|c|c|c|c|}
\hline \multirow{2}{*}{$\begin{array}{l}\text { Complex* } \\
\text { M(II) }\end{array}$} & \multirow[b]{2}{*}{ Colour } & \multirow{2}{*}{$\begin{array}{l}\text { m.p. } \\
\left({ }^{\circ} \mathrm{C}\right)\end{array}$} & \multicolumn{4}{|c|}{ Found (calcd) \% } & \multirow{2}{*}{$\begin{array}{c}\text { Molar } \\
\text { conduct }\left(\Omega^{-1}\right. \\
\left.\mathrm{cm}^{2} \mathrm{~mol}^{-1}\right)\end{array}$} & \multirow{2}{*}{$\begin{array}{l}\mu_{\text {eff }}^{+} \\
(\mathrm{BM})\end{array}$} \\
\hline & & & $\mathbf{M}$ & $\mathrm{Cl}$ & $\mathrm{N}_{2} \mathrm{H}_{4}$ & $\mathrm{~N}$ & & \\
\hline $\mathrm{I} ; \mathrm{Mn}$ & Yellow & 277 & $\begin{array}{c}13.00 \\
(13.01)\end{array}$ & $\begin{array}{c}16.78 \\
(16.81)\end{array}$ & $\begin{array}{c}7.32 \\
(7.38)\end{array}$ & $\begin{array}{c}13 \cdot 30 \\
(13 \cdot 26)\end{array}$ & $41 \cdot 30$ & $5 \cdot 70$ \\
\hline II; Co & Green & 240 & $\begin{array}{c}12.66 \\
(12.74)\end{array}$ & $\begin{array}{c}15 \cdot 30 \\
(15 \cdot 36)\end{array}$ & $\begin{array}{c}6.77 \\
(6.92)\end{array}$ & $\begin{array}{c}12.00 \\
(12.11)\end{array}$ & $73 \cdot 55$ & $4 \cdot 03$ \\
\hline III; $\mathbf{Z n}$ & White & 282 & $\begin{array}{c}14.91 \\
(15 \cdot 11)\end{array}$ & $\begin{array}{c}16 \cdot 11 \\
(16 \cdot 41)\end{array}$ & $\begin{array}{c}7.00 \\
(7.40)\end{array}$ & $\begin{array}{c}13.05 \\
(12.94)\end{array}$ & $24 \cdot 71$ & Dia. \\
\hline IV; Cd & White & 262 & $\begin{array}{c}23.33 \\
(23.43)\end{array}$ & $\begin{array}{c}14.68 \\
(14.80)\end{array}$ & $\begin{array}{c}6.59 \\
(6.67)\end{array}$ & $\begin{array}{c}11.46 \\
(11.67)\end{array}$ & $20 \cdot 37$ & Dia. \\
\hline $\mathrm{V} ; \mathbf{H g}$ & White & 208 & $\begin{array}{c}35.09 \\
(35.32)\end{array}$ & $\begin{array}{c}12.50 \\
(12.50)\end{array}$ & $\begin{array}{c}5.60 \\
(5 \cdot 63)\end{array}$ & $\begin{array}{c}9.72 \\
(9.88)\end{array}$ & $19 \cdot 62$ & Dia. \\
\hline $\mathrm{VI} ; \mathrm{Ni}$ & $\begin{array}{l}\text { Light } \\
\text { green }\end{array}$ & $240(d)$ & $\begin{array}{c}12.18 \\
(12.70)\end{array}$ & $\begin{array}{c}14.66 \\
(15 \cdot 37)\end{array}$ & $\begin{array}{c}6.69 \\
(6.92)\end{array}$ & $\begin{array}{c}11.72 \\
(12.12)\end{array}$ & $28 \cdot 29$ & $3 \cdot 10$ \\
\hline VII; Cu & Green & 183 & $\begin{array}{c}13.84 \\
(13.61)\end{array}$ & $\begin{array}{c}15 \cdot 30 \\
(15 \cdot 21)\end{array}$ & - & $\begin{array}{c}11.22 \\
(11.99)\end{array}$ & 39.29 & 2.07 \\
\hline VIII; $\mathbf{M n}$ & Brown & $260(d)$ & $\begin{array}{c}15.86 \\
(14.96)\end{array}$ & - & $\begin{array}{c}9.10 \\
(9.11)\end{array}$ & $\begin{array}{c}15 \cdot 12 \\
(15 \cdot 25)\end{array}$ & - & 5.94 \\
\hline IX; Zn & White & 282 & $\begin{array}{c}17.04 \\
(17.26)\end{array}$ & - & $\begin{array}{c}8.40 \\
(8.45)\end{array}$ & $\begin{array}{c}14 \cdot 16 \\
(14 \cdot 83)\end{array}$ & - & Dia. \\
\hline $\mathrm{X} ; \mathbf{H g}$ & $\begin{array}{l}\text { Greenish } \\
\text { yellow }\end{array}$ & $195(d)$ & $\begin{array}{c}39.10 \\
(39.11)\end{array}$ & - & $\begin{array}{c}5.92 \\
(6.24)\end{array}$ & $\begin{array}{c}10.91 \\
(10.92)\end{array}$ & - & Dia. \\
\hline XI; Co & Purple & 284 & $\begin{array}{c}9.69 \\
(9.07)\end{array}$ & - & $\begin{array}{c}9.50 \\
(9.85)\end{array}$ & $\begin{array}{c}17.04 \\
(17.24)\end{array}$ & - & $6 \cdot 28$ \\
\hline $\mathrm{XII} ; \mathrm{Cd}$ & $\begin{array}{l}\text { Light } \\
\text { yellow }\end{array}$ & $>300$ & $\begin{array}{c}15.34 \\
(15.94)\end{array}$ & - & $\begin{array}{c}9.01 \\
(9.08)\end{array}$ & $\begin{array}{c}15.77 \\
(15.89)\end{array}$ & - & Dia. \\
\hline XIII; Ni & $\begin{array}{l}\text { Light } \\
\text { brown }\end{array}$ & $>300$ & $\begin{array}{c}14.20 \\
(14.39)\end{array}$ & - & $\begin{array}{c}7.32 \\
(7 \cdot 84)\end{array}$ & $\begin{array}{c}13 \cdot 25 \\
(13 \cdot 72)\end{array}$ & - & 3.48 \\
\hline $\mathrm{XIV} ; \mathrm{Cu}$ & Green & 220 & $\begin{array}{c}15 \cdot 11 \\
(15 \cdot 43)\end{array}$ & - & - & $\begin{array}{c}13.51 \\
(13.60)\end{array}$ & - & 2.08 \\
\hline
\end{tabular}

*I-VII represent complexes with empirical formula $\mathrm{M}\left(2-\mathrm{ApBzGH} \mathrm{Cl}_{2} .2 \mathrm{H}_{2} \mathrm{O}\right.$; VIII-X, $\mathrm{M}(2-$ $\mathrm{ApBzGH}-\mathrm{H})(\mathrm{OH}) ; \mathrm{XI}-\mathrm{XII}, \mathrm{M}(2-\mathrm{ApBzGH}-\mathrm{H})_{2}$ and XIII, XIV, M(2-ApBzGH)(OH). $2 \mathrm{H}_{2} \mathrm{O}$ +dia. - diamagnetic

forms complexes of different compositions depending on the mode of preparation and metal ions. Formation of the adducts is favoured in weakly acidic conditions while the neutral complexes are isolated from mildly basic media. With few exceptions, the complexes are insoluble in water and common organic solvents. All the adducts are soluble in DMSO while the neutral complexes are sparingly soluble or insoluble in the solvent. All the complexes melt or decompose at specific temperatures except the neutral complexes of $\mathrm{Ni}(\mathrm{II}), \mathrm{Mn}(\mathrm{II})$ and $\mathrm{Cd}(\mathrm{II})$ which are nonmelting till $300^{\circ} \mathrm{C}$. The adducts show 1:1 electrolytic behaviour ${ }^{10}$ in DMSO solution. The insufficient solubility of the complexes in suitable solvents precluded the molecular weight determination and growing of single crystal for X-ray crystallographic studies.

\subsection{Magnetic measurements and electronic spectra}

The room temperature magnetic moments of the paramagnetic complexes are included in table 1 and the electronic spectral bands along with the corresponding assignments are given in table 2. $\mu_{\text {eff }}$ values of the $\mathrm{Mn}$ (II) and $\mathrm{Cu}$ (II) complexes are normal for five and 
Table 2. Absorption bands and the assigned transitions of the complexes*.

\begin{tabular}{|c|c|c|c|}
\hline Complex & $\begin{array}{l}\text { Band maxima } \\
\left(\mathrm{cm}^{-1}\right)\end{array}$ & $\begin{array}{l}\text { Transitions } \\
\left(\mathrm{cm}^{-1}\right)\end{array}$ & $\mathrm{B}^{\prime}\left(\mathrm{cm}^{-1}\right)$ \\
\hline II; Co & $\begin{array}{c}6250 \\
(14493,15038,16000)\end{array}$ & $\begin{aligned}{ }^{4} \mathrm{~A}_{2}(\mathrm{~F}) & \rightarrow{ }^{4} \mathrm{~T}_{1}(\mathrm{~F}) \\
& \rightarrow{ }^{4} \mathrm{~T}_{1}(\mathrm{P})\end{aligned}$ & 659 \\
\hline $\mathrm{XI} ; \mathrm{Co}$ & $\begin{array}{c}8620 \\
12346 \\
19608\end{array}$ & $\begin{aligned}{ }^{4} \mathrm{~T}_{1 \mathrm{~g}}(\mathrm{~F}) & \rightarrow{ }^{4} \mathrm{~A}_{2 \mathrm{~g}}(\mathrm{~F}) \\
& \rightarrow{ }^{4} \mathrm{~T}_{2 g}(\mathrm{~F}) \\
& \rightarrow{ }^{4} \mathrm{~T}_{1 \mathrm{~g}}(\mathrm{P})\end{aligned}$ & 808 \\
\hline VI; Ni & $\begin{array}{c}9750 \\
15873 \\
26667\end{array}$ & $\begin{aligned}{ }^{3} \mathrm{~A}_{2 \mathrm{~g}}(\mathrm{~F}) & \rightarrow{ }^{3} \mathrm{~T}_{2 \mathrm{~g}}(\mathrm{~F}) \\
& \rightarrow{ }^{3} \mathrm{~T}_{1 \mathrm{~g}}(\mathrm{~F}) \\
& \rightarrow{ }^{3} \mathrm{~T}_{1 \mathrm{~g}}(\mathrm{P})\end{aligned}$ & 885 \\
\hline XIII; Ni & $\begin{array}{l}11830 \\
18182\end{array}$ & $\begin{aligned}{ }^{3} \mathrm{~A}_{2 \mathrm{~g}}(\mathrm{~F}) & \rightarrow{ }^{3} \mathrm{~T}_{2 \mathrm{~g}}(\mathrm{~F}) \\
& \rightarrow \mathrm{T}_{1 \mathrm{~g}}(\mathrm{~F})\end{aligned}$ & 740 \\
\hline VII; Cu & 16000 & ${ }^{2} B_{1 g}(D) \rightarrow{ }^{2} B_{2 g}(D)$ & - \\
\hline XIV; Cu & 15385 & ${ }^{2} B_{1 g}(D) \rightarrow{ }^{2} B_{2 g}(D)$ & - \\
\hline
\end{tabular}

*The spectra are recorded as nujol mull

one unpaired electrons. The UV spectra of $\mathrm{Cu}$ (II) complexes are indicative of distorted octahedral geometry ${ }^{11}$ around the metal ions. $\mu_{\text {eff }}$ value and electronic spectral data of $\mathrm{Co}$ (II) adduct show metal ion in a tetrahedral geometry ${ }^{12} \cdot \mu_{\text {eff }}$ value of the deprotonated $\mathrm{Co}$ (II) complex is abnormal. In the absence of variable temperature magnetic moments ${ }^{11}$, no definite reason can be attributed for this observation. Although the number and positions of the spectral bands of the $\operatorname{Co}(2-\mathrm{ApBzGH})_{2}$ are inconsistent with an octahedral geometry, the assignment of the spin state in the ground term is of doubtful validity in view of its abnormal $\mu_{\text {eff }}$ values. An octahedral configuration ${ }^{13}$ for both Ni(II) complexes has been inferred from $\mu_{\text {eff }}$ values and electronic spectral features. The Racah-parameter values $\left(B^{\prime}\right)$ have been calculated for $\mathrm{Co}$ (II) and $\mathrm{Ni}(\mathrm{II})$ complexes. These values show considerable decrease suggesting a good overlap between metal-ligand orbitals ${ }^{14}$.

\subsection{IR spectra}

The bonding sites of 2-ApBzGH have been assigned by a careful comparison of IR spectra of the complexes with that of 2-ApBzGH (table 3). The Nujol mull IR spectrum of 2-ApBzGH shows bands at 1690, 1545 and $1310 \mathrm{~cm}^{-1}$ and 1630,1535 and $1305 \mathrm{~cm}^{-1}$ which may be assigned to amide I, II and III modes of the hydrazide and benzamide moieties ${ }^{8}$ respectively. The positions of the amide I, II and III bands arising from the benzamide $>\mathrm{C}=\mathrm{O}$ group remain almost unaltered in the spectra of all the complexes as compared to those of the metal-free ligand, suggesting non-involvement of the above group in bonding. However, the corresponding amide bands of the hydrazide $>\mathrm{C}=\mathrm{O}$ group appear in the $1675-1640,1515-1505$ and $1335-1325 \mathrm{~cm}^{-1}$ regions in the spectra of the adducts indicating its involvement in coordination ${ }^{15}$. These amide bands disappear from the spectra of all the neutral complexes and a sharp band diagnostic of the $>\mathrm{C}=\mathrm{N}-\mathrm{N}=\mathrm{C}<$ group appears at $1600-1590 \mathrm{~cm}^{-1}$ indicating destruction of hydrazide $>\mathrm{C}=\mathrm{O}$ through amide $\leftrightarrow$ imidol tautomerism and subsequent coordination through the imidol oxygen. The appearance of new peaks characteristic of $\left(\mathrm{NCO}^{-}\right)$in the $1515-1500$ and $1335-1330 \mathrm{~cm}^{-1}$ regions in the spectra of the neutral complexes further supports the coordination of the imidol group ${ }^{16}$. Coordination through azomethine nitrogen ${ }^{17}$ is suggested on the basis of the observed hypsochromic shift $\left(15-50 \mathrm{~cm}^{-1}\right)$ of the $(\mathrm{N}-\mathrm{N})$ and bathochromic shift 
Table 3. IR spectral data $\left(\mathrm{cm}^{-1}\right)$ of the complexes of $2-\mathrm{ApBzGH}$.

\begin{tabular}{|c|c|c|c|c|c|c|c|c|}
\hline \multirow{2}{*}{$\begin{array}{l}\text { Complex } \\
\text { M(II) }\end{array}$} & \multicolumn{4}{|c|}{ Hydrazidic moiety } & \multirow[b]{2}{*}{$\gamma(>\mathrm{C}=\mathrm{N}-\mathrm{N}=\mathrm{C}<)$} & \multirow[b]{2}{*}{$\gamma(\mathrm{C}=\mathrm{N})$} & \multirow[b]{2}{*}{$\gamma(\mathrm{NN})$} & \multirow[b]{2}{*}{$\gamma(\mathrm{MO})$} \\
\hline & Amide I & & & III & & & & \\
\hline 2-ApBzGH & $1690(v s)$ & 154 & & $1310(s)$ & - & $1585(s)$ & $1045(m)$ & - \\
\hline $\mathrm{I} ; \mathrm{Mn}$ & $1660(v s)$ & 151 & & $1330(s)$ & - & $1570(s)$ & $1070(s)$ & $380(m)$ \\
\hline II; Co & 1640 (vs) & 150 & & $1330(\mathrm{~m})$ & - & $1570(s)$ & $1075(s)$ & $385(w)$ \\
\hline III; $\mathrm{Zn}$ & $1670(v s)$ & 151 & & $1335(\mathrm{~m})$ & - & $1565(s)$ & $1080(s)$ & $380(\mathrm{~m})$ \\
\hline IV; Cd & $1660(s)$ & 151 & & $1325(\mathrm{~m})$ & - & $1570(m)$ & $1065(s)$ & $400(w)$ \\
\hline $\mathrm{V} ; \mathrm{Hg}$ & $1675(v s)$ & 151 & & - & - & $1570(w)$ & $1070(v s)$ & $360(w)$ \\
\hline $\mathrm{VI} ; \mathrm{Ni}$ & $1660(s)$ & 151 & & $1330(\mathrm{~m})$ & - & $1565(\mathrm{~m})$ & $1075(\mathrm{~m})$ & $350(w)$ \\
\hline \multirow[t]{2}{*}{ VII; $\mathrm{Cu}$} & $1660(v s)$ & 150 & & $1330(m)$ & - & $1545(s)$ & $1075(\mathrm{~m})$ & $340(w)$ \\
\hline & \multicolumn{4}{|c|}{$\gamma\left(\mathrm{NCO}^{-}\right)$} & & & & \\
\hline VIII; $\mathrm{Mn}$ & \multirow{7}{*}{\multicolumn{2}{|c|}{$\begin{array}{l}1510(\mathrm{~s}), \\
1510(\mathrm{~m}), \\
1515(\mathrm{~s}), \\
1500(\mathrm{~m}), \\
1510(\mathrm{~s}), \\
1515(\mathrm{~s}), \\
1515(\mathrm{~s}),\end{array}$}} & \multirow{2}{*}{\multicolumn{2}{|c|}{$1330(s)$}} & $1595(m)$ & $1565(s)$ & $1090(m)$ & $370(m)$ \\
\hline IX; Zn & & & & & $1595(\mathrm{~m})$ & $1565(\mathrm{~m})$ & $1060(w)$ & $390(\mathrm{~m})$ \\
\hline $\mathrm{X} ; \mathrm{Hg}$ & & & \multicolumn{2}{|c|}{$\begin{array}{l}1335(s) \\
1330(s)\end{array}$} & $1590(s)$ & $1565(s)$ & $1095(s)$ & $360(m)$ \\
\hline $\mathrm{XI} ; \mathrm{Co}$ & & & \multicolumn{2}{|c|}{$1335(v s)$} & $1595(s)$ & $1550(\mathrm{~m})$ & $1060(\mathrm{~m})$ & $385(m)$ \\
\hline XII; Cd & & & \multicolumn{2}{|c|}{$1335(s)$} & $1590(s)$ & $1565(\mathrm{~m})$ & $1075(\mathrm{~m})$ & $350(w)$ \\
\hline XIII; Ni & & & \multicolumn{2}{|c|}{$1335(\mathrm{~m})$} & $1595(s)$ & $1565(m)$ & $1060(\mathrm{~m})$ & $370(w)$ \\
\hline $\mathrm{XIV} ; \mathrm{Cu}$ & & & \multicolumn{2}{|c|}{$1335(s)$} & $1600(s)$ & $1565(\mathrm{~m})$ & $1060(\mathrm{~m})$ & $380(w)$ \\
\hline
\end{tabular}

*The spectra are recorded as nujol mull

$v s$ - very strong; $s$-strong; $m$ - medium; $w$ - weak

$\left(15-40 \mathrm{~cm}^{-1}\right)$ of the $(\mathrm{C}=\mathrm{N})$ bands in the spectra of all the complexes as compared to their appearance at 1045 and $1585 \mathrm{~cm}^{-1}$ respectively in the spectrum of the ligand. The hypsochromic shift observed in the pyridine ring breathing $\left(10-15 \mathrm{~cm}^{-1}\right)$, in-plane $(30$ $\left.35 \mathrm{~cm}^{-1}\right)$ and out-of-plane $\left(40-50 \mathrm{~cm}^{-1}\right)$ deformation modes indicates coordination of the pyridine ring nitrogen ${ }^{18}$. Appearance of a new band in the $1150-1145 \mathrm{~cm}^{-1}$ in the spectra of the neutral complexes attributable to the $\mathrm{M}-\mathrm{OH}$ bending indicates the formation of $\mathrm{M}$ $\mathrm{OH}$ bond in the complexes ${ }^{19}$. The bands appearing in the 400-340,380-315 and 290 $270 \mathrm{~cm}^{-1}$ regions in the spectra of the complexes may be tentatively assigned to the (M$\mathrm{O}),(\mathrm{M}-\mathrm{N})$ and $(\mathrm{M}-\mathrm{Cl})$ modes $^{20}$.

\subsection{ESR spectra}

The ESR spectra of the Cu(II) complexes are isotropic at room temperature but show anisotropic features at LNT and are characteristic of axial symmetry. The $g_{1}$ and $g_{\perp}$ values are 2.281 and 2.057 for $\left[\mathrm{Cu}(2-\mathrm{ApBzGH}) \mathrm{Cl}\left(\mathrm{H}_{2} \mathrm{O}\right)_{2}\right] \mathrm{Cl}$ and 2.256 and 2.071 for $[\mathrm{Cu}(2-$ $\left.\mathrm{ApBzGH}-\mathrm{H})(\mathrm{OH})\left(\mathrm{H}_{2} \mathrm{O}\right)\right]$ complexes, respectively. The trend $g_{1}>g_{\perp}>g_{\mathrm{e}}$ indicates tetragonal elongation along $z$-axis and presence of unpaired electron in $b_{1 \mathrm{~g}}\left(d_{x 2-y 2}\right)$ orbital $^{21}$. The in-plane $\sigma$-bonding parameter $\left(\alpha^{2}\right)$ calculated for these $\mathrm{Cu}(\mathrm{II})$ complexes, 0.69 and 0.79 predicts a predominant covalent in-plane bonding 22 .

\section{$3.4{ }^{1} \mathrm{H},{ }^{13} \mathrm{C}$ and ${ }^{113} \mathrm{Cd} \mathrm{NMR}$ spectra}

${ }^{1} \mathrm{H}$ and ${ }^{13} \mathrm{C}$ NMR spectral data of $2-\mathrm{ApBzGH}$ and the $\mathrm{Zn}(\mathrm{II}), \mathrm{Cd}(\mathrm{II})$ and $\mathrm{Hg}$ (II) complexes were recorded in DMSO- $\mathrm{d}_{6}$ and the spectral bands along with the assignments are given in tables 4 and 5 respectively. Although ${ }^{1} \mathrm{H}$ NMR spectrum of the ligand (figure 2) shows 
Table 4. ' $\mathrm{H}$ NMR spectral data $(\delta)$ of $2-\mathrm{ApBzGH}$ and its $[\mathrm{Cd}(2-\mathrm{ApBzGH}) \mathrm{Cl}] \mathrm{Cl}$ and $\left[\mathrm{Cd}(2-\mathrm{ApBzGH}-\mathrm{H})_{2}\right]$ complexes.

\begin{tabular}{|c|c|c|c|c|}
\hline \multirow[b]{2}{*}{ Proton(s) } & \multirow{2}{*}{$\begin{array}{l}\text { 2-ApBzGH } \\
(296 \mathrm{~K})\end{array}$} & \multicolumn{2}{|c|}{$[\mathrm{Cd}(2-\mathrm{ApBzGH}) \mathrm{Cl}] \mathrm{Cl}$} & \multirow{2}{*}{$\begin{array}{c}{\left[\mathrm{Cd}(2-\mathrm{ApBzGH}-\mathrm{H})_{2}\right]} \\
(296 \mathrm{~K})\end{array}$} \\
\hline & & $(296 \mathrm{~K})$ & $(343 \mathrm{~K})$ & \\
\hline Hydrazidic-NH- & $-10.85(s)$ & $11.42(s), 12.48(s)$ & $11 \cdot 13(s)$ & - \\
\hline Benzamide-NH- & $8.71(s)$ & $8.88(t), \quad 9.21(t)$ & $8.93(t)$ & $8.62(t)$ \\
\hline$-\mathrm{CH}_{2-}$ & $4.52(d)$ & $4.41(d), 4.58(d)$ & $4.50(d)$ & $4.01(d)$ \\
\hline$-\mathrm{C}_{\underline{\mathrm{H}}_{3}}-$ & $2 \cdot 38(s)$ & $2.41(s), 2.62(s)$ & $2 \cdot 50(s)$ & $2.50(s)$ \\
\hline \multirow[t]{4}{*}{ Ring protons } & $8.57(d)$ & $8.78(d)$ & $8.80(d)$ & $7.99(\mathrm{~m})$ \\
\hline & $7.91(\mathrm{~m})$ & $8 \cdot 17(m)$ & $8.21(d)$ & $7.54(b)$ \\
\hline & $87.52(m)$ & $87.93(m)$ & $88 \cdot 10(t)$ & - \\
\hline & - & $87.61(d)$ & $87.67(d)$ & - \\
\hline
\end{tabular}

$s$ - singlet; $d$ - doublet; $t$ - triplet; $m$ - multiplet

Table 5. Proton-noise decoupled ${ }^{13} \mathrm{C}$ NMR spectral data (ppm) of 2-ApBzGH and the $[\mathrm{Cd}(2-\mathrm{ApBzGH}) \mathrm{Cl}] \mathrm{Cl}$ complex.

\begin{tabular}{|c|c|c|c|}
\hline \multirow[b]{2}{*}{ Carbon atom } & \multirow{2}{*}{$\begin{array}{c}\text { 2-ApBzGH } \\
(296 \mathrm{~K})\end{array}$} & \multicolumn{2}{|c|}{$[\mathrm{Cd}(2-\mathrm{ApBzGH}) \mathrm{Cl}] \mathrm{Cl}$} \\
\hline & & $(296 \mathrm{~K})$ & (343 K) \\
\hline Hydrazidic $>\mathrm{C}=\mathrm{O}$ & 170.7 & $171 \cdot 1,171 \cdot 4$ & 169.6 \\
\hline Benzamide $>C=0$ & 167.0 & $166 \cdot 9$ & $166 \cdot 9$ \\
\hline$-\mathrm{H}_{3} \mathrm{C}$ & 11.8 & $11 \cdot 3,13 \cdot 2$ & - \\
\hline$-\mathrm{H}_{2} \mathrm{C}-$ & $41 \cdot 3$ & - & - \\
\hline$-\mathbf{N C}-$ & 153.0 & $150.5(d)$ & 150.9 \\
\hline$C(1)$ & $131 \cdot 3$ & 131.4 & 131.4 \\
\hline$C(2)$ & 128.2 & 128.6 & 128.9 \\
\hline$C(3)$ & $127 \cdot 3$ & 127.9 & $126 \cdot 9$ \\
\hline$C(4)$ & $134 \cdot 1$ & $133 \cdot 3$ & - \\
\hline$C\left(2^{\prime}\right)$ & 154.9 & 154.4 & - \\
\hline$C\left(3^{\prime}\right)$ & 123.9 & 123.5 & 123.8 \\
\hline $\mathrm{C}\left(4^{\prime}\right)$ & 135.5 & $136 \cdot 2$ & 135.9 \\
\hline$C\left(5^{\prime}\right)$ & 120.0 & $120-0$ & 121.6 \\
\hline$C\left(6^{\prime}\right)$ & 148.5 & $149.2(d)$ & - \\
\hline
\end{tabular}

$d$-doublet

that more than one isomer exists at room temperature, the extremely weak peaks due to the second isomer indicate its negligible contribution at $296 \mathrm{~K}$ to the overall structure of 2-ApBzGH. Stabilisation of the second isomer after complexation is being suggested by

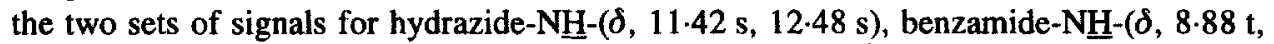
$9.21 \mathrm{t}), \mathrm{CH}_{2}-(\delta, 4.41 \mathrm{~d}, 4.58 \mathrm{~d}),-\mathrm{CH}_{3}(\delta, 2.41 \mathrm{~s}, 2.62 \mathrm{~s})$ in the ${ }^{1} \mathrm{H}$ NMR spectrum of [Cd(2$\mathrm{ApBzGH}) \mathrm{Cl}] \mathrm{Cl}$. These isomers are usually non-separable due to the relatively low barrier to rotation ${ }^{23}$. However as the temperature is raised, the coalescence of the peaks occur showing stabilisation of one of the conformers at a higher temperature. Figure 3 shows the signals due to hydrazidic $-\mathrm{NH}-$ and $-\mathrm{CH}_{2}-$ groups in the ${ }^{\mathrm{H}} \mathrm{H} \mathrm{NMR}$ spectrum of [Cd(2$\mathrm{ApBzGH}) \mathrm{Cl}] \mathrm{Cl}$ as a function of temperature. The hydrazidic $-\mathrm{NH}-$ signal appearing at $\delta 10.85$ in the spectrum of $2-\mathrm{ApBzGH}$ indicates a downfield shift at $\delta 12.52, \delta 12.48$ and 


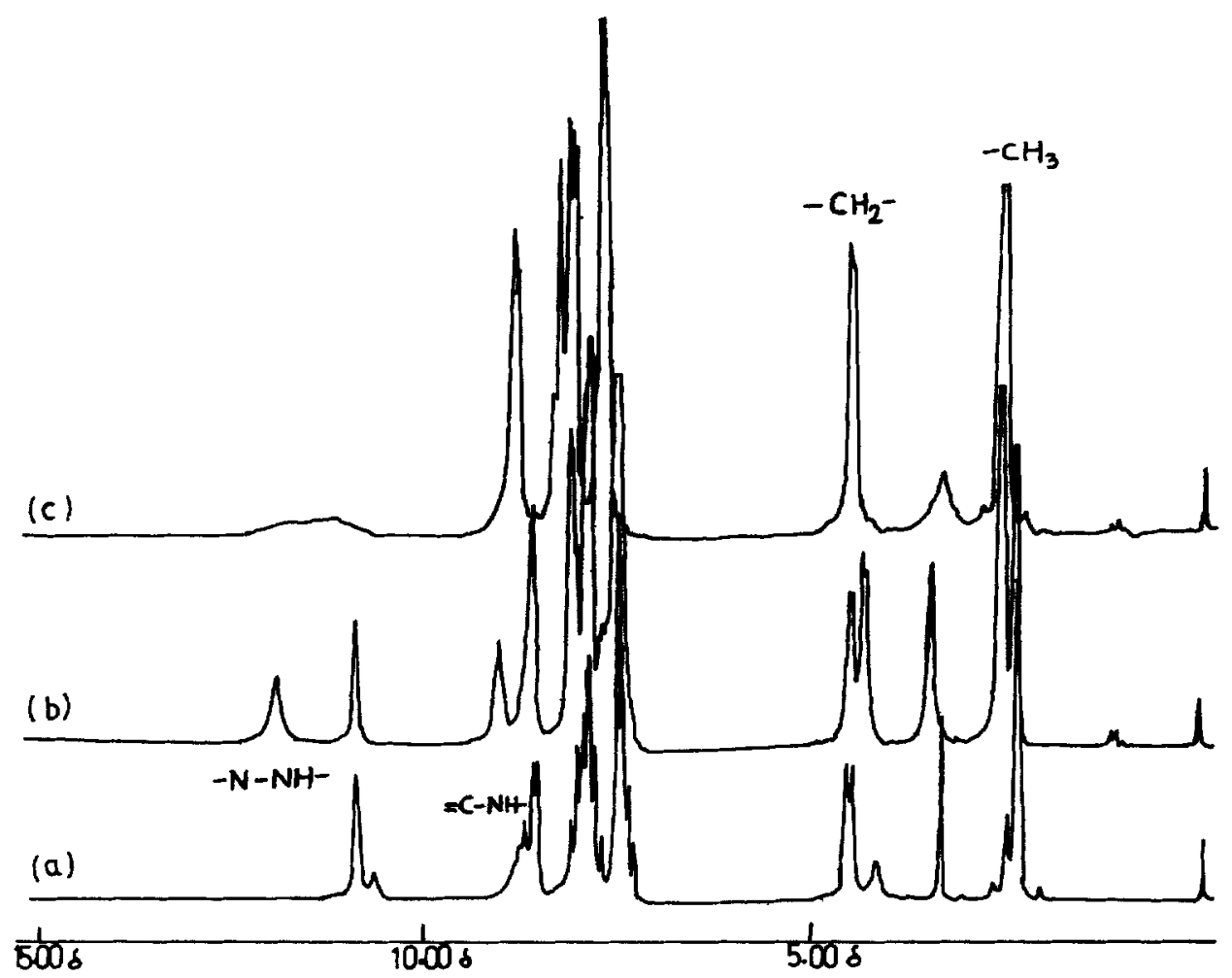

Figure 2. 'H NMR spectra of (a) $2-\mathrm{ApBzGH}$ at $296 \mathrm{~K}$; (b) $[\mathrm{Cd}(2-\mathrm{ApBzGH}) \mathrm{Cl}] \mathrm{Cl}$ at $296 \mathrm{~K}$ and $[\mathrm{Cd}(2-\mathrm{ApBzGH}) \mathrm{Cl}] \mathrm{Cl}$ at $343 \mathrm{~K}$.

$\delta 11.81$ for $\mathrm{Zn}(\mathrm{II}), \mathrm{Cd}(\mathrm{II})$ and $\mathrm{Hg}(\mathrm{II})$ adducts respectively suggesting coordination of $2-\mathrm{ApBzGH}$ through hydrazidic $>\mathrm{C}=\mathrm{O}$ and azomethine nitrogen ${ }^{24}$. In the ${ }^{1} \mathrm{H} \mathrm{NMR}$ spectrum of the $\left[\mathrm{Cd}(2-\mathrm{ApBzGH}-\mathrm{H})_{2}\right]$ complex, the signal due to imino-proton of the hydrazide moiety disappears thereby confirming deprotonation of the imino proton and bonding through imidol oxygen in the neutral complexes. The signals due to methyl and methylene protons do not show any significant shift in the spectrum of $[\mathrm{Cd}(2-$ $\mathrm{ApBzGH}) \mathrm{Cl}] \mathrm{Cl}$.

The ${ }^{13} \mathrm{C}$ NMR spectra (figure 4 ) of the complexes also show the splitting features of hydrazide $>\mathrm{C}=\mathrm{O}$ and $-\mathrm{CH}_{3}$ signals associated with the presence of more than one isomer of $2-\mathrm{ApBzGH}$ in the complexes at $296 \mathrm{~K}$. Coordination through hydrazidic $>\mathrm{C}=\mathrm{O}$ and azomethine nitrogen ${ }^{25,26}$ have been deduced from the shift of the $>\mathrm{C}=\mathrm{O}$ and -NC- resonance signals in the complexes (2-ApBzGH 170.7, 153.0 ppm; Zn(II) 171.7, 150.8; $\mathrm{Cd}$ (II) $171.4,150.5 \mathrm{ppm}$ and $\mathrm{Hg}$ (II) $171.7,150.8 \mathrm{ppm}$ ). The signals due to benzamide $>\mathrm{C}=\mathrm{O}$ and benzene ring carbons show no remarkable shift. Bonding through pyridine ring nitrogen ${ }^{26}$ is also shown by the downfield shift $(1.00-1.65 \mathrm{ppm})$ in the $\mathrm{C}\left(5^{\prime}\right)$ signal in the spectra of the complexes.

${ }^{113} \mathrm{Cd} \mathrm{NMR}$ spectrum of $[\mathrm{Cd}(2-\mathrm{ApBzGH}) \mathrm{Cl}] \mathrm{Cl}$ was recorded in DMSO-d $\mathrm{d}_{6}$ and the chemical shift was referenced to external $1.0 \mathrm{M} \mathrm{CdSO}_{4}$ in $\mathrm{H}_{2} \mathrm{O}$. The resonance signal of the complex was observed as a single line at $-347.9 \mathrm{ppm}$, which is unusually shielded. 

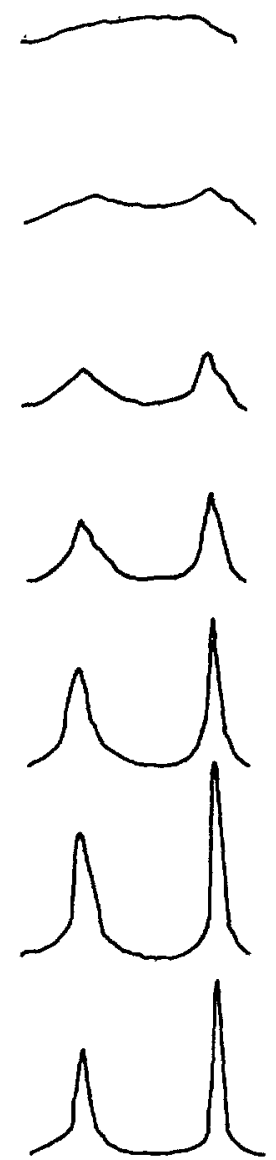

1300

(a)
$343 \mathrm{~K}$

$333 \mathrm{~K}$

$323 \mathrm{~K}$

$318 \mathrm{~K}$

$308 \mathrm{~K}$

$303 \mathrm{~K}$

$297 K$

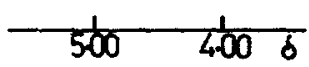

(b)

Figure 3. 'H NMR spectral peaks of $[\mathrm{Cd}(2-\mathrm{ApBzGH}) \mathrm{C}] \mathrm{Cl}$ as a function of temperature (a) Hydrazidic- $\mathrm{NH}-$ and (b) $-\mathrm{CH}_{2}-$ signals.

The shielded nature of this resonance reflects a strongly bound (nonexchanging) cadmium ion, but one which is electronically weakly coordinated i.e., the bonding in this system is more ionic rather than the usual donor-acceptor relation between a ligand and a metal 


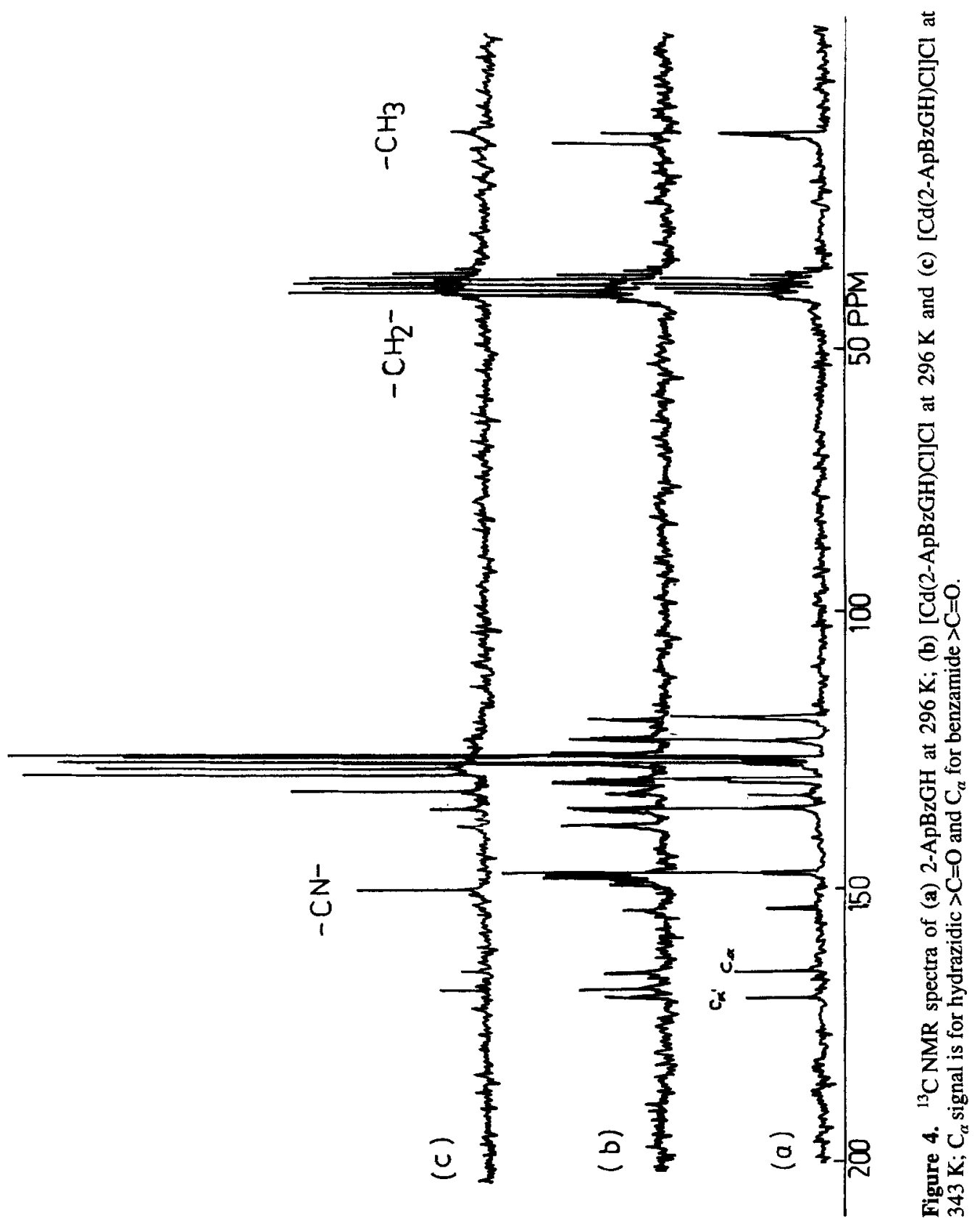




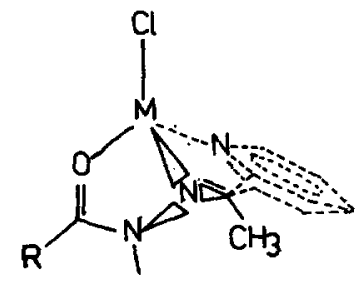

(a)

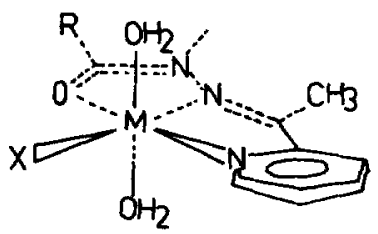

(b)

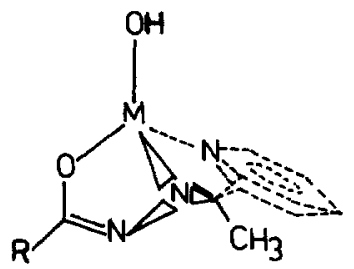

(c)

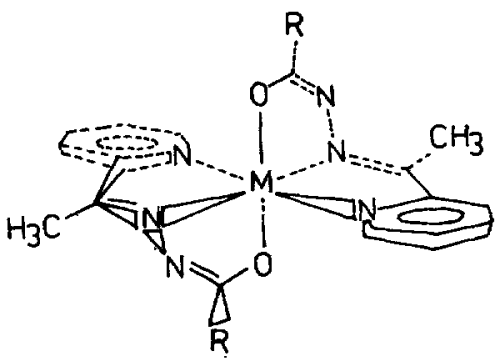

(d)

Figure 5. Proposed structures of the complexes (a) $\mathrm{M}=\mathrm{Mn}, \mathrm{Co}, \mathrm{Zn}, \mathrm{Cd}, \mathrm{Hg}$; (b) $\mathrm{M}=\mathrm{Ni}, \mathrm{Cu} ; \mathrm{X}=\mathrm{Cl} / \mathrm{OH}$; (c) $\mathrm{M}=\mathrm{Mn}, \mathrm{Zn}, \mathrm{Hg}$ and (d) $\mathrm{M}=\mathrm{Co}, \mathrm{Cd}$.

such as cadmium ${ }^{27}$. This highly shielded chemical shift value is also expected to have orthogonal environment ${ }^{28}$.

\subsection{X-ray diffraction studies}

The X-ray powder diffraction patterns of the complexes have been indexed successively ${ }^{29}$. The indexing of the pattern yields the lattice constants, $a=10.14 \AA$; $b=6.01 \AA ; c=5.65 \AA$ indicating an orthorhombic system for $[\mathrm{Cd}(2-\mathrm{ApBzGH}) \mathrm{Cl}] \mathrm{Cl}$ and 
$a=b=12.39 \AA ; c=19.25 \AA$ for $\left[\mathrm{Cu}(2-\mathrm{ApBzGH}) \mathrm{Cl}\left(\mathrm{H}_{2} \mathrm{O}\right)_{2}\right] \mathrm{Cl}$ showing its crystal to be tetragonal.

\section{Conclusion}

The analytical data of the complexes suggest that 2-ApBzGH can form complexes in both $1: 1$ and $1: 2$ ratio. The electrical conductance shows $1: 1$ electrolytic nature of the adducts. IR, ${ }^{1} \mathrm{H}$ and ${ }^{13} \mathrm{C}$ NMR spectra suggest tridentate behaviour of 2 -ApBzGH coordinating through hydrazidic $>C=O$, azomethine nitrogen and ring nitrogen as a neutral ligand in the adducts and uninegative ligand in the deprotonated complexes through keto-enol tautomerism. More ionic bonding in the complexes is being suggested by the highly shielded ${ }^{113} \mathrm{Cd}$ chemical shift value. Figure 5 shows the tentative structures proposed for the complexes.

\section{Acknowledgements}

We are thankful to the Head, Department of Chemistry, Banaras Hindu University for providing the laboratory facilities. One of us (RKL) also acknowledges the University Grants Commission, New Delhi for financial assistance.

\section{References}

1. Aggarwal R C and Prasad Rao D S S V 1982 Indian J. Chem. A21 735

2. Rao T R, Sahay M and Aggarwal R C 1984 Indian J. Chem. A22 214

3. Rao T R, Sahay M and Aggarwal R C 1985 Indian J. Chem. A24 244

4. Rao T R, Singh G, Sastry P S S J and Lonibala R K 1992 Synth. React. Inorg. Met.-Org. Chem. 221041

5. Rao T R and Kumar P A 1994 Bull. Chem. Soc. Jpn. 67100

6. Kumar P A and Rao T R 1997 Proc. Indian Acad. Sci. (Chem. Sci.) 10989

7. Singh G, Kumar P A and Rao T R 1994 J. Chem. Res. 861

8. Rao T R and Genda 1990 Indian J. Chem. A29 154

9. Vogel A I 1971 A textbook of quantitative inorganic analysis (London: Longmans)

10. Geary W J 1971 Coord. Chem. Rev. 781

11. Figgis B N 1976 Introduction to ligand fields (New York: John Wiley \& Sons) pp 226-290

12. Figgis B N and Lewis J 1964 Prog. Inorg. Chem. 6197

13. Henke W and Kremer S 1982 Inorg. Chim. Acta 65 L115

14. Lever A B P 1968 Inorganic electronic spectroscopy (Amsterdam: Elsevier)

15. El-Gayel E and Iskander M F 1971 J. Inorg. Nucl. Chem. 33107

16. Rao C N R 1963 Chemical application of infrared spectroscopy (New York: Academic Press) p. 265

17. Braibanti A, Dallavale and Pellinghelli 1968 Inorg. Chem. 71430

18. Nagano K, Kinoshita H and Hirakawa A 1964 Chem. Pharm. Bull. 121198

19. Nakamoto $K 1986$ Infrared and Raman spectra of inorganic and coordination compounds 4th edn (New York: Interscience) p. 230

20. Inomata T and Moriwaki T 1973 Bull. Chem. Soc. Jpn. 461148

21. Van Landschoot R C, Van Hest J A M and Reedjik J 1976 J. Inorg. Nucl. Chem. 384003

22. Rockenbauer A 1979 J. Magn. Res. 351979

23. Stewart W E and Sidall T H III 1970 Chem. Rev, 70517

24. Patil S A and Kulkarni V H 1984 Inorg. Chim. Acta 95195

25. Paolucci G, Marangoni G, Bandoli G and Clemente D A $1980 \mathrm{~J}$. Chem. Soc. (Dalton Trans.) 1304

26. Domiano P, Pelizzi C, Predieri G, Viglani C and Palla G 1984 Polyhedron 3281 
27. Marchetti P S, Bank S, Bell W T, Kennedy M A and Ellis P D 1989 J. Am. Chem. Soc. 111 2063

28. Honkonen R S and Ellis P D 1984 J. Am. Chem. Soc. 1065488

29. Azaroff L V and Buerger M J 1958 The powder method in X-ray crystallography p. 119 